BULLETIN Bulletin hispanique

HISPANIQUE Université Michel de Montaigne Bordeaux

$120-2$ | 2018

Varia

\title{
Muertes del autor: reflexiones en torno a la autoficción paródica
}

Les morts de l'auteur : réflexions autour de l'auto-fiction parodique

The author's deaths: reflexions around parodic self-fiction

\section{Ana Casas Janices}

\section{CpenEdition}

\section{Journals}

Edición electrónica

URL: https://journals.openedition.org/bulletinhispanique/6861

DOI: 10.4000/bulletinhispanique.6861

ISSN: 1775-3821

Editor

Presses universitaires de Bordeaux

Edición impresa

Fecha de publicación: 10 diciembre 2018

Paginación: 545-564

ISBN: 979-10-300-0337-6

ISSN: 0007-4640

\section{Referencia electrónica}

Ana Casas Janices, «Muertes del autor: reflexiones en torno a la autoficción paródica», Bulletin

hispanique [En línea], 120-2 | 2018, Publicado el 02 enero 2022, consultado el 08 enero 2022. URL:

http://journals.openedition.org/bulletinhispanique/6861 ; DOl: https://doi.org/10.4000/

bulletinhispanique.6861 


\title{
Muertes del autor: reflexiones en torno a la autoficción paródica ${ }^{1}$
}

\author{
Ana Casas Janices \\ Universidad de Alcalá
}

Les morts de l'auteur: réflexions autour de l'auto-fiction parodique

Le présent article analyse plusieurs romans contemporains dans lesquels les représentations textuelles de leurs auteurs meurent effectivement dans le monde de la fiction. Leur disparition en tant que personnages monopolise le discours parodique qui vise à subvertir certains codes que le lecteur connait bien, concrètement le rapport entre auteur et œuvre et les liens de cette dernière avec le référent.

Mots-clés : autofiction, mort de l'auteur, parodie, autodérision, roman contemporain.

El presente artículo analiza varias novelas contemporáneas en las que las proyecciones textuales de sus autores mueren efectivamente en el mundo de ficción. Su desaparición como personajes de novela centraliza el discurso paródico orientado a subvertir determinados códigos conocidos por el receptor, en concreto la relación autor-obra y sus vínculos con el referente.

Palabras clave: autoficción, muerte del autor, parodia, autoderrisión, novela contemporánea.

\section{The author's deaths: reflexions around parodic self-fiction}

The aim of this article is to analyze some contemporary novels in which the textual projection of the author actually dies in the fictional word. His/her disappearance as a character in the novel centralizes the parodic discourse in order to subvert certain codes that the reader knows well, such as the links between the author and his/her work and the links between the novel and its referent.

Keywords: autofiction, the death of the author, parody, self-deprecation, contemporary novel.

1. Este trabajo forma parte del proyecto «Figuraciones del yo y representación autoficcional en narrativa, cine, teatro y novela gráfica en el marco de la teoría de los géneros», financiado por el Subprograma Ramón y Cajal (MICINN-RYC) 2011. De igual modo se enmarca en los Proyectos del Plan Nacional «La autoficción hispánica. Perspectivas interdisciplinarias y transmediales. 1980-2013» (FFI2013-40918-P) y «Pensar lo real: autoficción y discurso crítico» (FFI2017-89870-P), financiados por el Ministerio de Economía y Competitividad.

Bulletin Hispanique, Tome 120, n 2 - décembre 2018 - p. 545-564. 
E n su última novela, Carsick: John Waters Hitchhikes across America (2014), el conocido cineasta describe el viaje en autostop que, a sus 66 años, lo llevó a cruzar el país con el objeto de escribir un libro sobre esta experiencia. Pero, antes de lanzarse de verdad a la carretera, Waters imagina "Lo mejor que podría pasar» $\mathrm{y}$ «Lo peor que podría pasar», dos posibilidades que textualmente se corresponden con la primera y la segunda parte del libro. (En la tercera cuenta, por fin, «Lo que realmente sucedió», o eso tiene que creer el lector si hace caso de lo que se dice en el prólogo). Son muchas las maravillas y muchos los horrores que experimenta el autor en cada una de las dos primeras partes (del sol radiante a la lluvia torrencial, de los fans de sus películas a los frikies que lo acosan o insultan, de los improvisados y estimulantes encuentros eróticos al abuso homófobo de los policías de Kansas), pero sobre todo merece la pena detenerse un instante en el final de «Lo peor que podría pasar», cuando Waters cuenta cómo un psicópata, movido por su «odio a todos los directores de películas de culto» (189), lo tortura hasta la muerte: sin atender a sus súplicas (el cineasta le promete no volver a hacer películas trash y pasarse al mainstream), el asesino acaba cortándole la cabeza y enviándolo derecho al infierno, un lugar donde se proyecta "en un loop infinito" Qué bello es vivir.

Evidentemente Waters fantasea con una parte de su vida que no ha tenido lugar (y es probable que tampoco lo tenga en el futuro), ya que relata una historia que está protagonizada por él, pero que no puede ser la suya: se trata, en este sentido, de una narración contrafactual (Colonna 2012: 90-91) que la realidad empírica no tiene reparos en desmentir. Esta ausencia de referencialidad choca, sin embargo, con un elemento que posee una carga referencial insoslayable: el nombre propio del autor arrastra, en efecto, "una suerte de fuerza magnética» que comunica «a todo lo que toca un aura de verdad» (Lejeune 1986: 71-72). A ello hay que unirle todas las características físicas y morales del narradorpersonaje, coincidentes con las que conocemos del John Waters auténtico ${ }^{2}$. De este modo, cabe leer Carsick - al menos sus dos primeras partes- como una autoficción: el autor figurado intensifica algunos rasgos identificadores con respecto a la persona real, al tiempo que presenta otros que invitan al distanciamiento. Esos otros elementos que orientan el texto hacia la ficción -habrá podido advertirse ya- tienen que ver con la deformación humorística a la que Waters somete su viaje imaginado -tanto en la versión positiva como en la negativa- y, muy particularmente, con la escenificación -no exenta de descripción grotesca- de su propia muerte.

Que el autor se autorrepresente en estas condiciones no es desde luego lo más habitual, pero tampoco es una completa rareza. Dos libros relativamente recientes muy celebrados por la crítica, como Summertime (2009) de J. M. Coetzee, y La carte et le territoire (2010), de Michel Houellebecq, también exploran esta posibilidad: en la primera una serie de personajes -conocidos, familiares

2. Abundan, por ejemplo, las alusiones a la edad del personaje así como a su característico bigotito pintado. 
y examantes de Coetzee $^{3}$ - trazan el retrato del autor durante una época muy concreta de su vida (los primeros años de la década de los 70) tiempo después de haberse producido su muerte; en la novela de Houellebecq, el autor aparece como un personaje secundario -aunque con un papel importante en el desarrollo de la trama- que acaba siendo asesinado, decapitado y descuartizado por un coleccionista de composiciones artísticas macabras ${ }^{4}$.

Ahora bien, al hilo de los ejemplos citados cabe preguntarse qué es lo que lleva a un autor a fantasear con su propia muerte y, sobre todo, a ponerla por escrito. Se trataría de un gesto radicalmente irónico, en el que se extreman hasta el paroxismo los planteamientos paradójicos que subyacen en toda autoficción: las marcas de autobiografismo -en especial la presencia del nombre propio, así como la caracterización del personaje, cuyos rasgos lo asimilan o aproximan al autor real- se combinan, contradiciéndose, con las marcas de la ficción. La paradoja reside, pues, en conceder un espacio privilegiado al autor, transformado en personaje de su propia obra, $y$, al mismo tiempo, en socavar su autoridad escenificando su muerte o desaparición. Una deriva en la que se diría aparecen implícitas determinadas concepciones críticas sobre el autor, como las que observa Lucille Kerr (1992: 3-4) a propósito de la frase final del relato "Borges y yo» (1957): "No sé cuál de los dos escribe esta página», que puede interpretarse, en efecto, como la formulación de una pregunta que queda sin respuesta en torno a quién escribe el texto. La distinción entre las dos versiones del autor ("yo» equivaldría a la persona biográfica, y «Borges» al autor como personalidad pública y figura textual) resulta, desde el punto de vista de Kerr, indecidible. "Borges y yo" funcionaría, de este modo, como una parábola sobre la dificultad de estabilizar la figura del autor o, incluso, de privilegiar un concepto unívoco que la describiera. El autor se resiste, pues, a existir solamente en un sentido o en otro, y aparece, al contrario, como una figura problemática y compleja, cuya conceptualización bascula entre las posiciones positivistas -que reforzarían la idea del autor como persona y, por lo tanto, se interesarían por las relaciones entre vida y obra, la biografía del autor o la autoridad atribuida a un texto- y otras nociones, como las desarrolladas por Barthes (1968) y Foucault (1969), que entenderían el autor como un fenómeno textual y discursivo. En lugar de resolver esta dicotomía -como tampoco han podido resolverla los críticos $-^{5}$, los textos en los que el autor se

3. La novela no tiene una voluntad testimonial, de modo que sería ingenuo tomar los diversos discursos del libro como testimonios de personas reales. Si lo son o son personajes con un trasunto real, poco importa para los fines de la novela, como puede verse en Pontón Gijón (2009).

4. Las similitudes con el relato de Waters son evidentes: de hecho, en un momento dado, éste exclama: «Ay, Dios, esto no puede ser verdad. No puedo escribir mi propia muerte. ¡Michel Houellebecq, uno de mis escritores preferidos, ya lo hizo! ¡Los lectores van a pensar que me estoy copiando!» (Waters 2014: 190).

5. Como anota Lucille Kerr (1992: 14), a pesar de las aportaciones del New Criticism o los trabajos de Barthes y Foucault, la autoridad del autor sigue siendo rehabilitada desde otras perspectivas, como la Fenomenología, la Hermenéutica, o parte de la crítica feminista y marxista. 
proyecta a través de una figuración ficcional -especialmente los que optan por representar su extinción-invitan a hacernos preguntas sobre la fuente del texto y su autoría, que, como en el relato de Borges, parecen no poder obtener una respuesta única.

\section{Yo ES OTRO}

Con el fin de introducir esa distancia irónica a la que antes se ha aludido, el mecanismo que emplean las novelas de Waters, Houellebecq o Coetzee -con todas las precauciones que se quiera tomar, ya que se trata de obras muy diferentes entre sí- parece radicar en la objetivación del autor. Waters-aunque narra desde la primera persona- se ve desde fuera, transformado en un personaje tan estrambótico, grotesco o delirante como los conductores que le salen al paso. Houellebecq ni tan siquiera ocupa un espacio protagónico: aunque se le menciona en alguna que otra conversación, no aparece en persona hasta la página 138 de la edición francesa. Coetzee, por su parte, se eclipsa en el relato -muerto ya, no puede participar en éste-, aunque lo recorre como una figura fantasmal, pues de él sabemos lo que otros personajes cuentan o recuerdan. Además, en el caso de las novelas de Coetzee y Houellebecq puede hablarse de identidad entre autor y personaje pero no de identidad entre autor y narrador. En Summertime, únicamente escuchamos la voz de Coetzee en aquellas partes que recogen fragmentos de sus cuadernos de notas - no sabemos si reales o noal inicio y al final del libro; el resto lo componen las entrevistas que un biógrafo del «autor fallecido» realiza a algunas personas que lo trataron en un momento $\mathrm{u}$ otro de sus vidas. Y en La carte et le territoire, la voz narradora se expresa en tercera persona y adopta mayoritariamente la perspectiva del protagonista -el artista plástico Jed Martin-, a todas luces un personaje de ficción.

En la literatura hispánica reciente también hay ejemplos en los que el autor, imaginándose otro, decide darse muerte: Penúltimos castigos (1983) de Carlos Barral, Cómo me hice monja (1993) de César Aira, El sitio de los sitios (1995) de Juan Goytisolo, El desbarrancadero (2001), La rambla paralela (2002) y El don de la vida (2010) de Fernando Vallejo, España (2008) y Aire Nuestro (2009) de Manuel Vilas, Disecado (2011) de Mario Bellatin, o El ciego en la ventana (2014) de Juan Antonio Masoliver Ródenas, son algunos de ellos. En todos estos relatos, las identidades de sus autores se ven, en efecto, comprometidas, parodiadas, subvertidas, a través de diversas estrategias de objetivación y distanciamiento con relación a la figura autorial hasta el extremo de decretar su muerte física.

\section{El autor como personaje protagonista}

Desde sus orígenes, la teoría de la autoficción ha privilegiado la identidad onomástica entre Autor, Narrador y Personaje protagonista. Ya Doubrovsky (1977), en su conocida respuesta al «pacto autobiográfico» de Philippe Lejeune 
$(1973,1975)^{6}$, hacía coincidir estas tres instancias en su novela Fils: como se puede leer en la contracubierta, la suya era «una narración de acontecimientos estrictamente reales», donde el narrador-protagonista y el autor llevaban el mismo nombre; aunque no se trataba de una autobiografía en sentido estricto, sino de una "autoficción» porque los mecanismos retóricos empleados eran similares a los de una novela -en este caso, la dicción estilística, basada en el flujo de conciencia y la asociación libre de ideas-. Pero, como advertía Lejeune (1986: 63-64) unos años más tarde, el lector, leyendo Fils, sí tenía la impresión de que Doubrovsky hablaba esencialmente de hechos reales; el empleo de nombres propios -en especial el del autor- no haría más que reafirmar esta idea.

Los trabajos de Vincent Colonna, para quien la autoficción no depende tanto de la autobiografía como de la novela, desbaratan de algún modo las equivalencias antes señaladas ${ }^{7}$. En su tesis de 1989, así como su libro de 2004, Colonna pone el acento en los aspectos imaginativos de la autoficción, al tiempo que flexibiliza los vínculos entre autor, narrador y personaje, admitiendo para dicha relación distintas gradaciones y modalidades (no hay necesidad, por ejemplo, de identidad onomástica completa). Aunque el crítico francés no menciona de manera explícita la posibilidad de que el personaje del autor no sea central en la obra ${ }^{8}$, el hecho de entender la autoficción como una variante de la novela abre la puerta a toda clase de planteamientos formales, incluido el desplazamiento del autor, en el marco de la diégesis, a posiciones marginales o no protagónicas.

Desde esta perspectiva, es posible considerar una obra como Penúltimos castigos como una autoficción: relatada en primera persona por un narrador innominado - de profesión escultor-, cuenta entre sus personajes secundarios con el poeta y editor Carlos Barral ${ }^{9}$. El retrato de éste está, pues, condicionado por la perspectiva del narrador, por las opiniones que de él tienen otros personajes y, casi en última instancia, por el propio Barral. Aunque, no hay

6. Incapaz de proponer títulos de obras para la casilla que combinaba el pacto novelesco y la identidad entre autor y personaje, Philippe Lejeune (1994: 70) se preguntaba entonces: «El héroe de una novela, ¿puede tener el mismo nombre que el autor? Nada impide que así sea y es tal vez una contradicción interna de la que podríamos deducir efectos interesantes. Pero, en la práctica, no se me ocurre ningún ejemplo».

7. Desde los planteamientos doubrovskianos la autoficción debe leerse como una deriva experimental de la autobiografía. Para un recorrido más amplio de las trayectorias seguidas por la teoría de la autoficción puede leerse Casas (2012: 9-33).

8. De las cuatro modalidades que observa Colonna en su libro (2004) con relación a la autoficción, el autor es un personaje protagonista en la autoficción fantástica y en la biográfica y no sería personaje en absoluto en el caso de la autoficción autorial o intrusiva -el autor se proyecta en la obra a través del comentario interno-. Sólo en la autoficción especular, de tener lugar una metalepsis del autor, éste podría intervenir en el relato como personaje no protagonista.

9. Algunos son de factura ficticia, pues carecen de referente extratextual, y otros tienen trasuntos reales. Entre los últimos, Yvonne Barral -mujer del poeta-y sus hijos; Carme Balcells, Beatriz de Moura, Mario Muchnik, del mundo editorial; los poetas Jaime Gil de Biedma, José Agustín Goytisolo y Ángel González; o los narradores Juan Marsé y Juan García Hortelano. 
que olvidarlo, las palabras y acciones de todos ellos están mediatizadas por el discurso del narrador: un personaje de ficción. Así, el foco del relato se concentra en las experiencias y reflexiones de este narrador, sobre todo a lo largo de la primera mitad de la novela. A partir de la segunda las apariciones de Barral se hacen cada vez más frecuentes a medida que va estrechándose la relación entre el escultor y el poeta (Arroyo 2011: 309). El declive físico y mental de ambos - los dos tienen una parecida dependencia del alcohol, problemas de salud y varias neurosis-, así como la crisis personal, profesional y creativa que están atravesando llegan a su culmen con la muerte de Barral en el penúltimo capítulo. La descripción del cadáver -ahogado en la playa- y, más tarde, del entierro lleva al narrador a «asumir como propia la muerte de mi amigo Barral» y, finalmente, a entender que dicha identificación sólo era subjetiva, ya que en el deterioro del poeta y también en su muerte no dejaba de ver un reflejo de su propia crisis: "La verdad es que Barral me importaba muy poco antes de que yo comenzara a vivir su agonía» (274-275). De este modo, el narrador toma las riendas de su relato $-\mathrm{y}$, suponemos, de su vida $-\mathrm{y}$ el personaje de Barral regresa a los márgenes de la novela antes de desaparecer definitivamente.

En casi todos los demás títulos, entre los citados, tampoco se da una coincidencia plena entre narrador y personaje-protagonista (serían una excepción Cómo me hice monja, de Aira, y El desbarrancadero, de Vallejo, en los que el narrador homodiegético sí se identifica con el personaje del autor): en Disecado, el «autor Mario Bellatin»-aunque muerto- es objeto de escrutinio por parte del narrador, que lo observa desde su cama; en La rambla paralela y El don de la vida, de Vallejo, el personaje que posee los rasgos del autor comparte protagonismo con otros personajes con los que se relaciona en pie de igualdad gracias a la estructura dialogada del relato; en El sitio de los sitios, de Goytisolo, el autor apenas es una sombra que ni tan siquiera posee un nombre (sólo las siglas J. G.) con el que identificar al hombre que muere en el Hotel Internacional, en el Sarajevo sitiado; El ciego en la ventana, de Masoliver Ródenas, extrema esta marginalidad del autor al desplazar su presencia a los paratextos no como narrador sino como personaje, viejo y degradado en el Prólogo, difunto ya en el Epílogo: un ausente protagonismo del que el autor está dispuesto a renunciar cuando, respondiendo en el Prólogo a la mujer que lo está entrevistando, afirma que «lo que yo pueda ser no cuenta nada» (2014: 11).

La prosa posmoderna de Manuel Vilas, por su parte, explora obsesivamente la identidad vacía del autor: en varios capítulos de sus fragmentadas novelas aparece no una sino muchas de sus figuraciones. En algunos casos -los menosel personaje Manuel Vilas coincide con la instancia enunciadora, expresándose por lo tanto en primera persona; en otros es un personaje apenas relevante para el desarrollo de la trama. Aunque a menudo es un escritor o poeta, no es raro tampoco que se dedique a otros menesteres: en España lo conoceremos como el comandante Vilas, el policía Manuel Vilas y el casero Manuel Vilas Vidal. 
Ciertos personajes funcionan igualmente como reverberaciones del autor gracias a la similitud fonológica de sus nombres con el de Manuel Vilas: así, John Vidal, Art Garfunkel Vidal, Richard Vilas o César Vilas. Llegando al extremo de incluir en Aire Nuestro a Manuela Vilas, una escritora zaragozana cuya fama se debe, antes que a sus obras, al hecho de haberse sometido a un cambio de sexo. Los juegos constantes en torno a la identidad del autor, el humorismo de la mayor parte de las historias, las continuas inverosimilitudes «impiden la conexión analógica entre personaje y autor real» (Gómez 2015: 158). Una actitud distanciada y escéptica con respecto a la propia noción de autoridad que se manifiesta de manera palmaria en los episodios en los que se alude a la muerte de Vilas: fallecido en 2049 de un cáncer de colon, resucita, en España, en el año 31.224 gracias a las artes de un vampiro-resucitador; en Aire Nuestro, en cambio, muere como consecuencia de un infarto, entrando en el Paraíso de la mano de Elvis Presley. Como acierta a señalar Cristina Gutiérrez (2015: 132-133), todas estas identidades múltiples -ninguna de ella, en consecuencia, atribuible al autor real- contribuyen a generar una «difuminación del yo por omnipresencia y mutación expandida».

\section{Desdoblamiento del autor}

La multiplicidad de las identidades del autor - o lo que es lo mismo, el cuestionamiento de su univocidad- desemboca en algunos casos en la diversificación de los narradores y de los puntos de vista. Algunos críticos, por ejemplo, no han dudado en leer Penúltimos castigos como la representación de la conciencia escindida de Barral. Para Molero de la Iglesia (2000: 370), los personajes del escultor y el poeta apuntan ambos a la figura del autor: sus parecidos procesos vitales expresarían la dualidad, la desintegración del yo, tantas veces abordada en la poesía de Barral. Por su parte, Susana Arroyo (2011: 303) ve en el escultor "un trasunto del hombre en que el escritor y editor catalán habría podido convertirse si hubiera seguido su vocación de artista plástico». Esas mismas lecturas interpretan la imagen de la muerte que recorre la novela -la que se ceba con Barral, pero de la que no sale indemne el artista- como el desacuerdo entre los distintos personajes del autor ${ }^{10}$ : a punto de perder su editorial, Barral se ve impelido a afrontar la desaparición de una

10. Resulta esclarecedor a este respecto este pasaje a cargo de Yvonne Barral, hablando de su marido con el narrador: «El que las gentes generalmente le atribuían, el del editor exigente, al mismo tiempo aristocrático y radical, que era también, más o menos, la figura despectiva e impertinente de los actos y reuniones sociales, era la forma de personaje más alejada de la persona, el menos real y el más controlado. En realidad el Barral de la gorrita, disfrazado de capitán Akhab o devoto de Ulises, hablando exagerada jerga marinera, era, por ejemplo, mucho más próximo a la persona real. Esas formas aparentemente pintorescas del personaje eran alcanzadas por las neuras y los estados psicopáticos mucho antes que las formas sociales, más ficticias y resistentes y apoyadas en el crédito de los demás. El Barral de la gorrita se desmoronaba más o menos en las crisis de esterilidad y de vacuidad intelectual [...]. El Barral de los cócteles era destruido sólo por el alcohol, cuando le llegaba la hora o por la enfermedad, como ahora» (Barral 1983: 113). 
de sus personalidades públicas -la que se corresponde con su faceta de editor$y$, en cierto modo, a dejar morir a uno de sus personajes para seguir viviendo (Arroyo 2011: 311).

Expresión también de la multiplicidad del sujeto es la estructura dialógica de La rambla paralela y El don de la vida, de Fernando Vallejo. Menos compleja desde el punto de vista formal, El don de la vida es un diálogo entre dos personajes: el viejo, que presenta muchas características del autor ${ }^{11}$, y su compadre, que es, en realidad, la Muerte, como descubrimos en la última página de la novela cuando el viejo sufre un infarto. En La rambla paralela, al contrario, el autor se desdobla en dos personajes muy parecidos: el viejo gramático -un escritor colombiano que viaja desde México a Barcelona, invitado a participar en la Feria del Libro- ${ }^{12}$ y un mexicano -o suizo, no queda claro- que conoce al primero desde hace tiempo, aunque en muchos pasajes también actúa como su conciencia fantasmal o post-mortem, dada su capacidad para entrar en la mente del viejo. Nos encontramos, de cualquier modo, ante una situación enunciativa caótica: la narración, que alterna la primera persona y la tercera, va de la introspección a la narración externa, así como de la descripción del presente a la evocación del pasado y la anticipación de un futuro presidido por la muerte. Estamos, pues, ante un relato alucinado, en el que las voces se entremezclan y confunden, y del que no es posible distinguir el diálogo con uno mismo del diálogo con el otro ${ }^{13}$.

Resulta casi imposible sustraerse del efecto espejo en esta clase de textos, incluso en aquellos casos en los que el narrador se distancia de manera explícita del autor: el narrador de Disecado asegura no haber conocido en persona a Mario Bellatin, de quien sí se declara lector, pero lo llama, en cambio, «iMi yo?n, un apelativo que luego sustituye por el nombre sufí de Bellatin (una letra del alfabeto árabe o griego) y finalmente por el nombre completo del escritor. Todas estas maneras de llamar al autor parecen aludir a la identidad inasible y fantasmal de éste -tan inasible y fantasmal como la del personaje del muerto en el que Bellatin se proyecta-, al tiempo que introduce la duda con respecto a las relaciones que ambos mantienen: «iMi yo?» podría ser, en efecto, un reflejo

11. No se dice su nombre, pero abundan los datos que permiten la identificación, como las referencias a los libros publicados por este personaje, los mismos que ha publicado Vallejo, así como la inclusión de experiencias autobiográficas que ya habían sido narradas en otras novelas anteriores.

12. Como en El don de la vida, en La rambla paralela el personaje también permanece innominado, aunque se facilita la identificación con el autor: como él, nació en Antioquia, vivió siendo joven en Roma y en Barcelona, luego se instaló en México, es homosexual, escribe... Además se repiten escenas de otras novelas y relatos autobiográficos de Vallejo: la muerte de la abuela y el padre, de la perra Bruja, la desaparición de la finca Santa Anita, etc.

13. En los últimos tiempos, el viejo tiene la costumbre «ya no sólo de hablar solo sino de reírse solo, como un loco». De igual modo, el mexicano se distancia en algunos momentos del viejo gramático: «Nunca he sido yo partidario de las opiniones drásticas. Él sí. Para él todo era blanco o negro, cielo o infierno" (Vallejo 2002: 27 y 50). Clemencia Ardila (2013: 83-93) observa no dos sino tres voces: «el autor-narrador» (el escritor mexicano), «el autor-gramático» (que desempeñaría una función metalingüística) y «el autor-escritor» (el Viejo). 
del autor de la instancia enunciadora. Un reflejo que los signos interrogativos ponen evidentemente en cuestión.

De igual modo, la conversación entre la narradora del Prólogo, en El ciego en la ventana, y el autor -que esta vez aparece con su nombre completo y sus dos apellidos- desliza la posibilidad del desdoblamiento cuando, en un determinado momento, ella muestra cierta confusión: «Esta misma entrevista -dice-, ¿quién la está escribiendo? A ti siempre te ha encantado escribir entrevistas imaginarias» (2014: 15). Como en los casos anteriores, la confusión de la narradora no oculta -al contrario, potencia- el artificio inherente a tales desdoblamientos.

\section{El relato post-mortem}

En La rambla paralela, Vallejo, "vuelto fantasmal» (Musitano 2012: 4), mezcla los espacios, los tiempos, las voces, las perspectivas, situando la narración al margen de la verosimilitud realista. Ya en El desbarrancadero había abordado el relato de la muerte del autor desde parámetros similares: Fernando -llamado así en la página 136- recuerda una visita a la casa familiar para asistir a su hermano Darío, enfermo de SIDA en fase terminal y, entre relatos entreverados - unos recuerdos arrastran otros-, narra su propia muerte en México después de que le comuniquen por teléfono el fallecimiento del hermano (2014: 158-159). En La rambla paralela Vallejo también fantasea con su muerte, que en esta novela tiene lugar en las primeras páginas, durante el sueño del viejo, y vuelve a relatarse al final aunque con pequeñas variaciones.

En ambos libros se juega con la posibilidad de que todo el relato sea una evocación de la vida del personaje, ya que, desde la muerte, no es necesario respetar ninguna cronología y se pueden confundir los espacios y las experiencias. Esta reducción al absurdo de la vida también está presente -aunque desde una perspectiva más lúdica- en Cómo me hice monja, de César Aira. En el desenlace de la novela sabremos que el niño Aira -narrador en primera persona de su propia historia- muere a los seis años a manos de la mujer del heladero, cuando ésta lo mata en un acto de venganza (el padre de Aira, a su vez, había matado al marido de aquélla). El final «imposible» -en este punto el lector tiene que aceptar que ha estado leyendo el relato de un muerto- nos obliga a examinar la narración en su conjunto desde una lógica distinta a la realista, y más cercana, en cambio, a lo grotesco y delirante. La distancia entre el autor empírico y el autor figurado no puede ser aquí mayor.

\section{El autor espectral}

Martina Wagner-Egelhaaf evoca la figura del fantasma para hablar de autoficción. Partiendo de las ideas de Jacques Derrida desplegadas en Spectres de Marx (1993) cuando éste afirma que lo espectral es aquello "que no es ni 
sustancia ni esencia ni existencia, no está nunca presente como tal» (Derrida 2003: 12), la autora alemana piensa en las relaciones entre vida y escritura como algo que transgrede la frontera entre existencia y libro: «el yo autoficcional es capturado en el hechizo espectral de su propia mirada; es decir, puede ser percibido porque dicha mirada lo constituye, aunque no se deja ver» (WagnerEgelhaaf 2012: 243). Así, en las autoficciones la figura del autor recuerda a menudo la figura del fantasma, pues al tiempo que recorre el texto es incapaz de afirmar su autoridad sobre él.

El sitio de los sitios, de Juan Goytisolo, lleva al límite esta visión escéptica del autor, cuya figura, por otro lado, está presente desde el inicio de la novela. El libro empieza con el relato "Visión de invierno», en el que un narrador heterodiegético narra la muerte de un viajero, al que sólo lo identifican las siglas J. G., y la posterior -y muy misteriosa- desaparición del cadáver. Además de las siglas, que el lector está impelido a considerar coincidentes con las de Juan Goytisolo, algunas informaciones dispersas refuerzan los paralelismos entre el personaje y el autor real, pues ambos comparten edad, fecha de nacimiento y orientación sexual, entre otras características. No obstante, como señala Marco Kunz (2003: 204), la "verdadera identidad [del viajero] se diluye en un vertiginoso juego de enmascaramientos y espejismos», ya que su parecido con el autor se ve muy pronto cuestionado por otro de los personajes de la novela, el comandante español de la Fuerza Internacional de Interposición que investiga el caso, cuando afirma que las siglas J. G. «en nuestro país [...] abundan como las aves en el cielo y los peces en el mar: una lista de Juanes Pérez y Josés González podría componer por sí sola el censo de una población como La Coruña» (Goytisolo 1995: 41) ${ }^{14}$. Más adelante, el escritor e hispanista de la Tertulia Políglota -responsable, junto con sus colegas, de urdir la farsa del muerto extraviado- confesará cómo tiempo atrás compró a un chamarilero los poemas de un tal J. G., procedentes del archivo de un hospital psiquiátrico madrileño donde dicho poeta estuvo recluido después del alzamiento nacional por «sodomita inveterado, perverso y esquizofrénico» (126), y cómo utilizó la identidad de éste para suplantar la del viajero fallecido, de nombre «real» Yahya Sidi Abú Al Fadaíl ${ }^{15}$. Complicándose todavía más la situación, el lector descubrirá poco después que, por esos azares de la vida, las siglas del poeta republicano son tal vez una máscara utilizada por Eusebio, el tío homosexual del comandante que también pasó un tiempo ingresado en un psiquiátrico durante los años de la Guerra Civil.

14. Este mismo personaje demuestra conocer al autor de Coto vedado al que, en cambio, no identifica con el hombre que se esconde tras las siglas «J. G.» (Goytisolo 1995: 43).

15. Entrecomillo «real» porque, aunque ese es el nombre que figura en su pasaporte marroquí, el apellido coindice sospechosamente con el del santo almohade objeto de la tesis doctoral de otro miembro de la Tertulia Políglota, el historiador y, a la sazón, recepcionista del Hotel Internacional de Sarajevo. Éste expresa, además, sus dudas acerca de la autenticidad del pasaporte. 
De este modo, los capítulos de El sitio de los sitios -relatos, sueños, cartas, informes, poemas- funcionan como una suerte de telaraña textual, en la que intervienen diversos narradores -que son los «autores» de esos relatos, sueños, cartas, informes, poemas-, narratarios - pues varios de los textos se dirigen a un interlocutor- y también lectores -unos narradores leen a otros, llegando a manipular y modificar los textos que leen-, generando así una suerte de polifonía que impugna cualquier noción de autor mínimamente estable. Se trata, como anota Maria Laura Piccioni (2011:2-3), de textos «des-autorizados» que aluden «a la búsqueda de un autor» que se resiste a materializarse.

\section{PAROdia DE LOS TEXTOS, PARODIA DEL AUTOR}

La novela de Juan Goytisolo subraya la idea de la obra como un palimpsesto en el que se pierde el referente extratextual, incluido el propio autor. Por mucho que éste resulte aludido en distintas ocasiones, siempre subyace con respecto a él la noción de máscara, de simulacro, de figuración discursiva. Las siglas-que apelan al nombre tanto en presencia como en ausencia- revelan a la vez que ocultan la imagen de un autor que sólo lo es en la medida que ocupa un lugar dentro del discurso. Dicho de otro modo, el posible yo real -o yo íntimo- del autor se manifiesta únicamente a través de la escritura (Richard 2013: 83).

En El sitio de los sitios son los textos, efectivamente, los que generan la imagen artificial y fantasmática del autor. Como también es artificial y fantasmática, en justa correspondencia, la imagen de los personajes, cuyas identidades han sido veladas. Al igual que con el difunto J. G., los nombres de muchos de ellos han sido manipulados, reducidos a siglas, suprimidos. En una nota al pie, el compilador constata, por ejemplo, que el grado y las iniciales del militar español han sido sustituidos "por los de un anónimo "comandante", tal vez para borrar las pistas (Goytisolo 1995: 20). Otros narradores carecen directamente de nombre, como el hispanista-escritor, el historiador-recepcionista del Hotel Internacional o el compilador; a algunos apenas los identifican unas siglas, como sucede con J. M. M. -el internista navarro de Médicos Sin Fronteraso el músico judío D. K.; y también es posible, como en el caso de Sidi Abú Al Fadaíl, que no lleven su auténtico nombre. Que sean narradores en gran número, que los testimonios de unos rebatan los testimonios de otros, es un elemento más de "des-autorización». Lo es igualmente el hecho de que alguno de ellos se descubra siendo un personaje de ficción, como le sucede al comandante durante la lectura de «El enemigo mortal», uno de los relatos que aparece entre los papeles del viajero y cuyo protagonista se entretiene inventado versiones ficticias del asedio "supuestamente escritas por un comandante anónimo de la F. I. de Interposición» (92). Aunque más adelante sabremos que se trata de una de las trampas pergeñadas por el hispanista de la Tertulia Políglota, la duda acerca de qué es real y qué es ficción en El sitio de los sitios se instala en el texto para no abandonarlo, contaminando cualquier idea que podamos hacernos 
acerca de la autoría de los relatos que componen la novela ${ }^{16}$. Por extensión, la figura del Autor en mayúsculas también se ve empañada.

Así, pues, la dimensión paródica de la obra de Goytisolo relaciona de manera problemática los acontecimientos narrados - con toda su carga de verdad referencial en torno al sitio de Sarajevo y de compromiso del autor con respecto a dichos acontecimientos- con las diversas manifestaciones de la autoconsciencia narrativa. Tanto es así que todos los textos de la novela, en especial los informes y las cartas - pero también los relatos que se encuentran dentro de las coordenadas del realismo literario-, pierden su valor referencial, situándose al mismo nivel que las narraciones distópicas sobre el asedio del barrio parisino -en las que se reproducen en un futuro no lejano las condiciones del sitio de Sarajevo-, el cuento «El enemigo mortal» en torno a la figura fantástica del doble o los poemas escatológicos de Sidi Abú Al Fadaíl.

$\mathrm{Y}$, sin embargo, el enredo textual que es El sitio de los sitios se explica como una forma de resistencia frente a la barbarie muy real de nuestro mundo: «Víctimas de este sitio medieval [...] -dice un miembro de la Tertulia Políglota- decidimos responder, por nuestra cuenta, con la astucia, también medieval, de la diseminación de textos...» (126). Cabe hablar entonces, como se hacía al inicio de este trabajo, de distancia irónica, en la medida en que si bien se subvierten determinados códigos conocidos por el receptor (la relación autor-obra y sus vínculos con el referente), ello se hace, de forma paradójica, desde la continuidad de dichos códigos, ya que la referencialidad del yo -en especial su alcance ético- persiste en cierto sentido. Como obra que toma conciencia de sí misma, en la que el autor solo lo es por virtud de la pluma y no porque transcienda de ningún modo los márgenes del libro, El sitio de los sitios establece un diálogo con la tradición literaria a través de la diversidad de formas y géneros convocados.

También lo hacen otras novelas, entre las que decretan literal y simbólicamente la muerte del autor. "La desnudez de las propias angustias sin aparato literario tiende a ser obscena y resulta aburrida» (Barral 1983: 138), afirma el narrador de Penúltimos castigos. Aunque, luego, en el postrer capítulo, descubramos que el texto es una larga carta, una "confesión", dirigida al médico que, a lo largo del último año, ha estado tratando al escultor en la clínica en la que éste sigue internado, sería una ingenuidad por nuestra parte sentirnos tentados a realizar una lectura referencial del texto.

Todavía más subversiva con respecto a los géneros referenciales es Cómo me hice monja, de César Aira. En este caso el texto utiliza los tópicos del relato factual al inicio y no al final de la novela, al presentarse desde las primeras líneas como una narración rememorativa en primera persona de aparente contenido autobiográfico que incluye la promesa de narrar el proceso por el cual «me hice monja»y «tomé los hábitos» (Aira 2014: 11). No obstante, el

16. Como advierte Marco Kunz (2003: 202), «la autoría supuesta de un capítulo se pone en tela de juicio en los siguientes, de modo que el lector, que al leer el comienzo todavía cree pisar tierra firme, se adentra poco a poco en el territorio de la incertidumbre y la duda». 
relato va derivando paulatinamente en una disparatada y divertida historia, plagada de incongruencias y contradicciones que pone en entredicho cualquier clase de veracidad. De este modo, y a pesar de la identificación -sobre la que se insiste en numerosas ocasiones- entre el autor y quien narra ${ }^{17}$, el relato insiste en la paradoja genérica: genérica en un sentido tanto literario como sexual, pues el narrador habla de sí mismo en femenino, pero aquellos que lo interpelan utilizan, en cambio, el masculino; $y$, por otro lado, son continuas las violaciones del código autobiográfico y realista gracias a superponer a dichos códigos otros discursos que los invalidan, como lo grotesco (la monja enana que en el hospital intercede ante la Virgen para que cure a los niños), lo paródico (el narrador asimila las historias del radioteatro para construir sus propias fantasías) o lo delirante (la muerte de Aira a los seis años a manos de la mujer del heladero $)^{18}$. Desbaratada la posible lectura autobiográfica, la violación de la regla afecta a todos los elementos de la novela, anulando la excepcionalidad del acontecimiento imposible (no hay mayor inverosimilitud que el propio relato post-mortem). En consecuencia, el relato se muestra " "naturalmente" artificial, inventado e implausible» (Pron 2010: 114) ${ }^{19}$.

Un último ejemplo de obra que activa explícitamente procedimientos paródicos con respecto a su matriz genérica es El ciego en la ventana, de Juan Antonio Masoliver Ródenas, cuyo contenido memorialístico se ve cuestionado desde la propia estructura del relato, en extremo fragmentaria. Los episodios y acontecimientos se suceden, así, de manera caótica en forma de pequeñas narraciones, contradiciendo cualquier clase de cronología; utilizan todos los tiempos verbales -no sólo los del pasado, a menudo también el presente de indicativo; y mezclan el recuerdo de épocas pretéritas con la ficción en estado puro. La voz del relato -que podríamos identificar con la del autor al incluir ésta numerosos datos biográficos de aquél- se presenta como una voz múltiple, contradictoria: a veces evocadora y reflexiva, otras veces escatológica y obscena, impide de cualquier modo fijar la identidad del yo referido/construido. Los

17. Cuando otros personajes se dirigen a él lo llaman por su nombre: «César», «Cesítar», «Aira» o "César Aira».

18. Precisamente, «esta impresión queda refrendada por el final imposible desde la verosimilitud realista y desde la veracidad autobiográfica, ante el cual el lector no le queda otra alternativa que interpretar el relato de acuerdo con una lógica novelesca antirrealista» (Alberca 2003: 335). En este sentido, Pron (2010: 117) aventura una hipótesis bastante plausible con respecto al significado del enigmático título. Según él, podría tratarse de un juego de palabras - de nuevo la carga humorística- habitual en el Río de la Plata, que, en ciertos círculos, consiste en invertir las sílabas de las palabras: así, "cómo me hice monja» vendría a ser "cómo me hice jamón», o sea, fiambre, cadáver.

19. Añade Pron (2010: 116-117): «Al confesar su naturaleza ficticia, Cómo me hice monja propone una paradoja cuya función parece ser doble: por una parte, narrar una historia atípica incapaz de ser asimilada a las formas convencionales de la narración y, por otra parte, poner de manifiesto de manera irónica el carácter convencional de los aspectos que determinan nuestra aproximación a la literatura y su propia "verdad" en el marco de un rechazo más general a las formas estandarizadas del relato». 
paratextos introducen, además, una serie de reflexiones metaliterarias que moldean el horizonte de expectativas del lector, potenciando la ambigüedad del relato. El Prólogo insiste, por ejemplo, en la idea de inevitabilidad de la ficción en el seno de cualquier narración autobiográfica:

El escritor, no importa si cronista de toros, reseñador o articulista, novelista o poeta, es esencialmente vanidoso y lo que pretende en último término es imponer su yo, aunque sea, como en el caso de un diario, imponérselo a sí mismo, a su espejo exclusivo, a un yo que al ser escrito se convierte en tú. Y para seducir hay que inventar, hay que acudir a la invención. Por eso suelen estar tan cercanas las memorias de un escritor a sus novelas. (Masoliver 2014: 27-28)

Estamos, pues, como se dice en el epílogo, ante un relato que no quiere negar el pasado, pero sí «negar que val[ga] la pena recuperarlo a través de la escritura» (133). Contra la linealidad y la trama, la novela de Masoliver defiende, al contrario, lo inacabado, como inacabada queda -en un bucle metaficcional- la novela que está escribiendo cuando, como se narra en las últimas páginas, su yo figurado o ficcional muere apoyado en la ventana.

\section{AutoderRisión EN LA CONSTRUCCIÓN DEL PERSONAJE-AUTOR}

La autoficción, como la expresión de un rechazo -o cuando menos de una actitud de perplejidad- ante la supuesta factualidad del autor, no duda en extremar determinados mecanismos disruptivos y paradójicos, entre ellos las diversas categorías del humor (Casas 2015). Concretamente la «autoderrisión», en la acepción que emplea Bernat Castany a propósito de la obra de Fernando Iwasaki, es el principal mecanismo que utilizan las novelas de las que se ocupa este trabajo. Se trata de una "técnica retórica que consiste en la confesión o exhibición, por parte de un hablante, de sucesos o aspectos ridículos asociados a su persona, con el objetivo de atenuar su pretendida superioridad en tanto que crítico o satírico y propiciar, así, la identificación con sus interlocutores» (Castany 2015: 371). Sus formas van del humor festivo y carnavalesco con el que Manuel Vilas se burla de sí mismo al cinismo nihilista, por ejemplo, de Fernando Vallejo. Las posibilidades, en realidad, son casi infinitas, en la medida en que dependen del estilo de cada escritor.

Teniendo, pues, la autodeprecación como meta, sí puede advertirse cómo las novelas sobre la muerte del autor coinciden en tipificar los rasgos de éste, en lugar de elaborar un carácter que dote al personaje de una psicología compleja. Lejos de poseer una referencialidad que señale a la persona real, la versión ficticia del autor lo convierte en un tipo que, por sus rasgos -a menudo ridículos y caricaturescos- se opone a la imagen idealizada de la que tradicionalmente ha sido objeto el artista, una imagen en el fondo tan tipificada como esta otra que ahora se nos muestra. Como señala Manuel Alberca (2007: 24), en la autoficción en general abunda «la imagen de un creador improductivo y parásito, un misántropo de frágil personalidad y de 
autocaracterización grotesca y denigratoria, cuando no se conforma con la mediocridad del oficinista o burócrata que gestiona con ombliguismo autista su carrera literaria». En Penúltimos castigos, Carlos Barral aparece dibujado, efectivamente, como un intelectual grandilocuente, pedante y snob; como alguien deprimido y alcoholizado, que «se creía brillante cuando bebía mucho y en realidad se ponía reiterativo y, si no estúpido, por lo menos muy pesado» (1983: 98-99). El escritor-protagonista de La rambla paralela, de Fernando Vallejo, es merecedor, por su parte, de esta extensísima lista de improperios:

... un irreligioso, un anticlerical, un ateo, un incrédulo, un impío, un matacuras, un escupehostias, un irreverente, un indiferente, un impenitente, un reincidente, un laico, un jacobino, un volteriano, un anticatólico, un antiaspostólico, un antirromano, un librepensador, un enciclopedista, un relapso, un teófobo, un clerófobo, un blasfemador, un indevoto, un tibio, un descreído, un nefrítico, ¡un nefario! (Vallejo 2002: 98-99).

Además de los aspectos morales o intelectuales a través de los que se denigra la figura del autor, las novelas de Barral y Vallejo, pero también de otros, se regodean en los rasgos físicos de sus personajes. Así, algunos retratos poco amables destacan la «desproporcionada cabeza» de Manuel Vilas (2012: 228) o el aire de "pajarraco» de José Antonio Masoliver (2014: 7). Atención aparte merece la descripción de funciones fisiológicas, en especial las excretoras, que tiene por objeto depreciar la imagen del autor. El desbarrancadero, por ejemplo, muestra a Vallejo orinando con «el sexo estúpido» (2014: 125), y Manuel Vilas, al descubrir después de resucitado que su muerte se debió a un cáncer de colon, exclama con sorna: "Ya sabía que el culo me mataría» (2002: 230).

Pero si hay un aspecto del cuerpo que se reitera en todos estos autores es el de la decadencia física y la enfermedad que acompañan la vejez. Así, abundan los detalles sobre el progresivo deterioro del escritor (la caquexia que consume a Barral y sus dificultades para andar con el bastón) o las señales más obvias de la ancianidad (el rostro "de piel arrugada, de cejas tupidas y apagados ojos», de Vallejo, 2002: 124-125). Hay incluso quien, como Mario Bellatin, sigue envejeciendo aún después de muerto. Y también quien siente que la decadencia física y la decadencia intelectual van de la mano, como en El ciego en la ventana, en cuyo prólogo la narradora-entrevistadora recuerda cómo, tan sólo un año atrás, el escritor

... hablaba y te incitaba a hablar, te daba la razón, te la quitaba, cambiaba de tema cuando le convenía, te recomendaba los cinco o seis libros que había leído aquella semana mientras lamentaba el estado de la literatura. Su vitalidad era contagiosa y agotadora; su memoria, apabullante, y seguía manteniendo el aspecto de alguien que si no cultiva el deporte no es porque no esté en forma sino porque lo desprecia. (Masoliver 2014: 7)

Ahora, en cambio, le abre la puerta el mismo hombre pero con «los botones de la camisa mal abrochados, la bragueta abierta, en zapatillas, mal afeitado, y con restos de comida en la pechera y en la comisura de los labios. [...] Más que hablar balbucea» (7). 
La descripción de la muerte del autor, así como su entierro, es otro de los momentos que restan solemnidad al retrato del escritor. En Penúltimos castigos la muerte de Carlos Barral compone una escena cargada de patetismo pero también de vulgaridad: ahogado en la playa, el cadáver está «boca abajo, con la cara oculta en la arena y los brazos tendidos hacia adelante, las piernas un poco abiertas y los pies descalzos hacia atrás, al final de dos carriles, como si lo hubieran arrastrado" (1983: 245). Lo que no es óbice, además, para que su velatorio se narre con sutiles pinceladas de humor, en especial la reunión de poetas (muchos de ellos miembros de la Escuela de Barcelona) que discuten sobre si aprovechar o no la ocasión para redactar un texto de reconocimiento generacional ${ }^{20}$. Otras formulaciones son ya deliberadamente humorísticas, como la muerte por infarto de Manuel Vilas, en Aire Nuestro, y sobre todo la secuencia en la que su viuda, de camino a los Pirineos donde piensa esparcir las cenizas, detiene el coche para hacer un trío con sus amigos y acompañantes Azucena y Gregorio mientras «las cenizas de Vilas permanecen inalterables en el asiento de atrás del Peugeot 206» (2009: 134). En esta misma novela también acaba en orgía sexual la entrada de Vilas en el Paraíso, lugar donde, a falta de cuerpos, se confunden las voluptuosas identidades de los allí presentes.

Más cercano a lo grotesco, Vallejo, aparte de narrar con su singular estilo descarnado su propia muerte ${ }^{21}$, la emprende en El desbarrancadero con los de la Funeraria, a los que hubo que "darles mordida para que lo cremaran, según sus deseos", para acabar negando cualquier clase de transcendencia al hecho de desaparecer:

Entré al horno desnudo, avanzando sobre una banda mecánica. Y no bien transpuse la boca ardiente del monstruo, umbral de la eternidad, estallé en fuegos de artificio. En la más espléndida explosión de chispas verdes, rojas, violáceas, amarillas. ¡Tas, tas, tas, viva la fiesta, qué hijueputa! Me sentí una pila de Bengala de esas que quemábamos en navidad en Antioquia. (Vallejo 2014: 159) 22

Si bien es cierto que la idea de la muerte es omnipresente en la obra de Vallejo y que ésta responde a una visión muy particular de la existencia, próxima a los postulados filosóficos de Cioran (Diaconu 2013), también hay que reconocer que conecta a la perfección con las implicaciones simbólicas que

20. Después de la escena del velatorio, desaparece el humor: los pescadores -con los que Barral, al parecer, se sentía muy identificado- sacan el féretro de la casa y con él recorren el camino hasta el cementerio del pueblo costero -trasunto de Calafell- en el que se desarrolla la novela.

21. «Me encontraron con el aparato en la mano, azuloso, translúcido, rígido, cual un San José estofado tallado en madera. Como no alcancé a colgar, la llamada desde Medellín le costó a Carlos, que fue el que la hizo, lo que valía esa casa» (Vallejo 2014: 158).

22. Esta perspectiva sobre la muerte se repite en otras novelas del autor. Así, en La rambla paralela, también se narra la cremación del cadáver, esta vez en tercera persona: «En la Agencia Gayosso de México lo cremamos cumpliendo su última voluntad: "Nada para los gusanos, todo para las llamas". Luego repatriamos las cenizas a Colombia en una caja de zapatos. Y hoy quién sabe dónde yacen. En un jardín... En un alcor... En un collado...» (Vallejo 2002: 100). 
Castany (2015) advierte en la autoderrisión. La estrategia permite, en efecto, reírse de un colectivo concreto -en este caso el de los escritores-, al plantear el desdén por la obra y negar la imagen del artista inteligente, yendo en contra de concepciones muy arraigadas con respecto al hecho literario y sus contextos. Algunas voces se oponen precisamente a estos postulados construyendo versiones incongruentes o «idiotas» del autor, como ocurre con César Aira, en Cómo me hice monja y en otros muchos textos suyos (Premat 2009: 245); otras rebajan el valor de la propia obra, como hace Juan Antonio Masoliver cuando, aprovechando el juego de palabras, llama a sus textos «monotonías» ${ }^{23}$; y hay también quien elabora imágenes del vacío en torno a todo aquello que rodea la figura del autor: así, la escuela de escritores en la que está prohibido escribir o el congreso de dobles de escritores (Disecado de Mario Bellatin).

Todos estos ejemplos pueden llevarnos a pensar en el autor desde el concepto de paratopía señalado por Dominique Maingueneau (1993) con relación al escritor. La localización paradójica de éste en el campo literario, desubicada y contradictoria - pertenece a él y no pertenece a él, adopta sus reglas al tiempo que busca alterarlas y subvertirlas- se extiende a la figura del autor proyectada en la obra. Los textos aducidos escenifican, en este sentido, esa relación conflictiva -qué duda cabe de su actitud irreverente con respecto a las reglas genéricas-, así como la presencia no unívoca del autor -y su experiencia biográfica- en sus propias narraciones. Los relatos en los que se escenifica la muerte del autor parecen extremar estos debates, en la medida en que el autor como fuente de autoridad aparece erosionado sólo después de haberse llevado a cabo una vuelta aparente a la representación y a la referencialidad.

No obstante, también es posible percibir en la narración de la muerte del autor la imagen de la alteridad. Proyectándose en la obra como otro, el escritor universaliza su experiencia y la conecta con mayor facilidad con la del lector. Su muerte no refleja únicamente su propia desaparición, sino también la de quien es testigo de ella a través de la lectura. Desde esta perspectiva, la extinción del autor posee una dimensión no sólo literaria, sino también existencial. "A mí que no me vayan a promover homenajes cuando me muera que no los quiero. Ni crucifijos, ni discursos, ni flores, ni entierro, ni ninguna de esas faramallas» (Vallejo 2010: 21), dice el protagonista de El don de la vida, notando la insignificancia de cualquier vida y de cualquier muerte. La autoderrisión potenciaría estos significados, pues, a menudo «tenemos la sensación de que el autor, el narrador o el personaje que se ríe de sí mismo se está riendo también de la humanidad en su conjunto, de la que él no sería más que un ejemplar» (Castany 2015: 372). Frente a la afirmación de la identidad que podría extraerse de una lectura ingenua de estas obras, las novelas en torno a la muerte del autor expresan el borrado del yo, resaltando el vacío y la ausencia de un sujeto -ya no sólo un autor- que se sabe tan único como conmutable.

23. «Son tonías porque son de Tono... [...] se llaman monotonías y no monótonas, son como sinfonías o como variantes sobre un mismo tema» (Masoliver 2014: 14). 


\section{Bibliografía}

Aira César, 2014, Cómo me hice monja [1993], Barcelona: Debolsillo.

Alberca Manuel, 2003, «La autoficción hispanoamericana actual: disparate y autobiografía en Cómo me hice monja de César Aira», en Jacques Soubeyroux, Le Moi et l'espace. Autobiographie et autofiction dans les littératures d'Espagne et d'Amérique latine, Saint-Étienne, Université de Saint-Étienne, 329-338.

Alberca Manuel, 2007, El pacto ambiguo. De la novela autobiográfica a la autoficción, Madrid, Biblioteca Nueva.

Ardila Clemencia J., 2013, «Fernando Vallejo: autoguardado», en Antonio J. Gil González, Las sombras del novelista, AutoRepresentacioneS \#3, Binges, Orbis Tertius, 81-93.

Arroyo Redondo Susana, 2011, La autoficción. Entre la autobiografía y el ensayo biográfico. Limites del género, Tesis de doctorado, Universidad de Alcalá. Disponible en https://ebuah.uah.es/dspace/handle/10017/16941, consultado el 10 de octubre de 2014.

Barral Carlos, 1983, Penúltimos castigos, Barcelona, Seix Barral.

Barthes Roland, 1968, "La muerte del autor» (trad. C. Fernández Medrano). Disponible en https://teorialiteraria2009.files.wordpress.com/2009/06/barthes-lamuerte-del-autor.pdf, consultado el 19 de abril de 2015.

Bellatin Mario, 2011, Disecado, Madrid, Sexto Piso.

Casas Ana, 2012, «El simulacro del yo: la autoficción en la narrativa actual», en Ana Casas, La autoficción. Reflexiones teóricas, Madrid, Arco Libros, 9-42.

Casas Ana, 2015, «Desmontando al autor: ironía, parodia y sátira en la narrativa y el cine autoficcionales», Tropelías. Revista de Teoría de la Literatura y Literatura Comparada, 24. 174-190. Disponible en https://papiro.unizar.es/ojs/index.php/ tropelias/article/view/1153/1016, consultado el 20 de noviembre de 2015.

Castany Bernat, 2015, «La autoderrisión en la obra de Fernando Iwasaki», Pasavento. Revista de estudios hispánicos, III:2. 371-392. Disponible en http://www.pasavento. com/pdf/06_07_castany.pdf, consultado el 20 de noviembre de 2011.

Coetzee J. M., 2010, Verano. Escenas de una vida de provincias III [2009], Barcelona, Mondadori.

Colonna Vincent, 1989, L'autofiction. Essai sur la fictionalisation de soi en littérature, Lille, ANRT (microfiches no 5650). Disponible en https://tel.archives-ouvertes.fr/ tel-00006609/document, consultado el 20 de noviembre de 2015.

Colonna Vincent, 2004, Autofiction \& autres mythomanies littéraires, Auch, Tristam.

Colonna Vincent, 2012, "Cuatro propuestas y tres deserciones (tipologías de la autoficción)» [2004], en Ana Casas, La autoficción. Reflexiones teóricas, Madrid, Arco Libros, 85-122.

Derrida Jacques, 2003, Espectros de Marx: el estado de la deuda, el trabajo del duelo y la nueva Internacional [1993], traducción de José Miguel Alarcón y Cristina de Peretti, Madrid, Trotta.

Diaconu Diana, 2013, Fernando Vallejo y la autoficción. Coordenadas de un nuevo género narrativo, Bogotá, Universidad Nacional de Colombia. 
Doubrovsky Serge, 1977, Fils, París, Galilée.

Foucault Michel, 1969, «¿Qué es un autor». Disponible en https://azofra.files.wordpress.com/2012/11/que-es-un-autor-michel-foucault.pdf consultado el 19 de abril de 2015.

Gómez Sonia, 2015, "Juegos autoficcionales en la obra de Manuel Vilas», Pasavento. Revista de estudios hispánicos, III:1. 155-169. Disponible en http://www.pasavento. com/pdf/05_11_gomez.pdf, consultado el 20 de noviembre de 2015.

Goytisolo Juan, 1995, El sitio de los sitios, Madrid, Alfaguara.

Gutiérrez Valencia Cristina, 2015, "Ad jocis ad seria: la risa ambivalente en la obra humorística de Manuel Vilas», Pasavento. Revista de estudios hispánicos, III:2. 121-141. Disponible en http://www.pasavento.com/pdf/06_06_gutierrez.pdf consultado el 20 de noviembre de 2015.

Houellebecq Michel, 2010, La carte et le territorie, Paris, Flammarion.

Kerr Lucille, 1992, Reclaiming the author. Figures and fictions from Spanish America, Durham, Duke University Press.

Kunz Marco, 2003, Juan Goytisolo. Metáforas de la migración, Madrid, Verbum.

Lejeune Philippe,1973, "Le pacte autobiographique», Poétique. Revue de théorie et analyse littéraires, 14. 137-162.

Lejeune Philippe, 1975, Le Pacte autobiographique, París, Seuil.

Lejeune Philippe, 1986, Moi aussi, París, Seuil.

Lejeune Philippe, 1994, El pacto autobiográfico y otros estudios, trad. Ana Torrent, Madrid, Megazul-Endymion.

Maingueneau Dominique, 1993, Le contexte de l'œuvre littéraire. Enonciation, écrivain, société, Paris, Dunod.

Masoliver Ródenas Juan Antonio, 2014, El ciego en la ventana. Monotonías, Barcelona, Acantilado.

Molero de la Iglesia Alicia, 2000, La autoficción en España: Jorge Semprún, Carlos Barral, Luis Goytisolo, Enriqueta Antolin y Antonio Muñoz Molina, Berna, Peter Lang.

Musitano Julieta, 2012, "Detrás de una máscara fantasmagórica. Una lectura de La rambla paralela de Fernando Vallejo", Orbis Tertius, 18. 1-10. Disponible en http://www.memoria.fahce.unlp.edu.ar/art_revistas/pr.5363/pr.5363.pdf, consultado el 19 de abril de 2015.

Piccioni Maria Laura, 2011, "Los juegos del autor en El sitio de los sitios de Juan Goytisolo. Borramiento, presencia y compromiso político», en Raquel Macciuci, Diálogos transatlánticos. Memoria del II Congreso Internacional de Literatura y Cultura Españolas Contemporáneas. Volumen III: Literatura, arte, cine, otros medios: diálogos, cruces y convergencias, La Plata, FAHCE-UNLP, 1-9. Disponible en http://sedici.unlp.edu.ar/bitstream/handle/10915/31882/Documento_completo. pdf?sequence=1, consultado el 3 de noviembre de 2015 .

Pontón Gijón Gonzalo, 2009, «La autobiografía según J. M. Coetzee (a propósito de Summertime)», Quimera. Revista de Literatura, 312. 20-24.

Premat Julio, 2009, Héroes sin atributos. Figuras de autor en la literatura argentina, Buenos Aires, Fondo de Cultura Económica.

Pron Patricio, 2010, «De qué hablamos cuando hablamos del autor: la autoficción de 
César Aira en Cómo me hice monja», en Vera Toro, Sabine Schlickers y Ana Luengo, La obsesión del yo. La auto(r)ficción en la literatura española y latinoamericana, Frankfurt/Madrid, Vervuert/Iberoamericana, 111-121.

Richard Annie, 2013, L'autofiction et les femmes: un chemin vers l'altruisme?, París, L'Harmattan.

Vallejo Fernando, 2002, La rambla paralela, Madrid, Alfaguara. Vallejo Fernando, 2010, El don de la vida, México, Alfaguara.

Vallejo Fernando, 2014, El desbarrancadero [2001], México, Alfaguara.

Vilas Manuel, 2009, Aire Nuestro, Madrid, Alfaguara.

Vilas Manuel, 2012, España [2008], Madrid, Punto de Lectura.

Wagner-Egelhaaf Martina, 2012, «La autoficción y el fantasma» [2008], en Ana Casas, La autoficción. Reflexiones teóricas, Madrid, Arco Libros, 237-258.

Waters John, 2014, Carsick. De Baltimore a San Francisco con el Pontifice del Trash, Buenos Aires, Caja Negra. 